\title{
Language Use: Code Mixing, Code Switching, Borrowing, Pidginization, and Creolization
}

\author{
Komang Trisna Dewi \\ UHN I Gusti Bagus Sugriwa Denpasar \\ trisnadewi053@yahoo.com
}

\begin{abstract}
This study was conducted to gather sufficient information on the language use: code mixing, code switching, borrowing, pidginization, and creolization. The method used in this study is through a literature study that collects several previous studies to answer about code mixing, code switching, borrowing, pidginization, and creolization purposes. The results of this study that code can be a variety related to the element of language like sentence, clause, phrase and word which have the limitation because the code which is chosen by the speaker based on his/her necessity in communicating. CodeMixing is the mix of code from two languages or more in some content of conversation in form of a sentence, while Code-Switching defined as a term which is used to indicate exchange of two or more languages, varieties of language, and can be also an exchange in style. Moreover, Borrowing is the process of importing linguistic items from one linguistic system into another, a process that occurs any time two cultures are in contact over a period of time. Furthermore, Pidginization is a simplification of code of language which has arisen as the result of contact between people of different languages usually formed a mixing of the languages. When pidgin develops to creole, it is described as creolization. Creole is a pidgin which is modified and appropriated in its structure and vocabulary.
\end{abstract}

Keywords: code mixing, code switching, borrowing, pidginization, and creolization

\section{Introduction}

Language is a human behavior which can be studied from several different points of view: social, cultural, psychological...etc. Sociolinguistics is concerned with the study of language in relation to society. In social studies, language can be studied either for its use or functions. Language use is not be apart by culture, age, social status, and gender. It can be seen by the situation surrounding. Language sits the important role in our life in due to we can give the ideas, thought, etc. The linguist Roman Jacobson (cited in Yusuf,, 1994: 95), states that language function is the factor in speech act, which depends on the factors will be focused on in speech act.

In this case, language use or the use of language is how the language is used in Communication or the function of language. In monolingual society, people use only one language in communicating with others, meanwhile in bilingual society, people use two or more languages or codes. This study aims at exploring some of the sociolinguistic patterns of language use in bilingual or multilingual situations. Some terms used interchangeable by the general public, but have specific meanings and differences in linguistics, those are code-mixing, code-switching, 
borrowing, pidginization and creolization.

\section{Discussions}

\subsection{Language Use}

Language use symbolically represents fundamental dimensions of social behavior and human interaction states by Wolfram (1991). The notion is simple, but the ways in which language reflects behavior can often be complex and subtle. Furthermore, the relationship between language and society affects a wide range of encounters--from broadly based international relations to narrowly defined interpersonal relationships.

In this case, language use or the use of language is how the language is used in communication, or the function of language. And there are some types of language use which will be discussed later, such as: code-mixing, code-switching, borrowing, pidginization and creolization that will be discussed based on its definition, types and functions.

\subsection{Code Mixing Definition of Code-Mixing}

Hudson (1990) as cited in Paul (2013) states that in code-mixing, the bilingual individual shifts from one language to another according to the change of the situation. In codemixing, the speaker (who interacts with other bilinguals) changes from one code to another in the same situation. He defines code-mixing as the use of some words from a language, then some words from the other language and coming back to the first language and so on. According to him, the main purpose of this mixing is to cope with an ambiguous situation in which no single code is appropriate. For example, Algerian students, at the French department, often mix French and Arabic when interacting with their class mates. Shifting from one language to another depends on many factors such as: gender, situation, and style...etc.

Wardaugh (1998) defined that code mixing occurs when conversations use both languages together to extent that they change from one language to the order in the course of a single utterance.

Whereas, Muysken (2000) uses the term 'code-mixing' to describe a situation where there is a combination of lexical and grammatical features of distinct languages in one sentence. It should be mentioned that many individuals mix sentences in their daily conversations. There are, of course, psycholinguistic and sociolinguistic factors which affect code-mixing, some important of which degree of bilingual proficiency, political balance between the languages, topic, setting and participants.

The other definitions about code mixing occurs when the conversant mix two or more languages in a speech or in a discourse without any requirement, the relaxed of the speaker or his/her habit get involved in that situation. The prominent characteristic in code mixing is the quality of being relaxed 
or informal situation. In a formal language situation, there are rarely mixed code. If there is mix code in the formal situation, it is because there is no proper expression in a language that is being used so it is necessary to use words from foreign languages. Sometimes there are also mixes the code if the speaker wants to show his knowledge or his position. (Nababan, 1991:32 as cited in Wisesa, 2012).

\section{Types of Code Mixing}

Suwito (1985:78) as cited in Suryani (2013) classifies code mixing into six types according to the linguistic elements that involved in code mixing as follows:

1. The insertion of words

This type is refers to language unit which consist of free morphemes of one language inserted into another language structure in uttreance or text.

Example: Made sudah lama desperate dengan keadaan fisiknya.

\section{The insertion of phrases}

This type of code mixing is refers to the insertion of a phrase or group of two or more related words into another language structure in the utterance or text. The phrase does not have subject or predicate.

Example: Ketut bekerja di sebuah event organizer.

\section{The insertion of hybrids}

This type of code mixing is refers to the combination of word pieces. This word pieces is the result of the mix between one word from language $A$ and one word from language $\mathrm{B}$.

Example: The combination pieces of indonesian and english word $d i-$ translate, nge-date.

Lebih baik teks itu di-translate saja.

4. The insertion of word reduplication

This type of code mixing is refers to the repetition some part or the entire part of the base word more than one word. It is a morphological process in which the word is repeated. The function in to show the plurality and intensification.

Example: Kabar kita disini fine-fine aja kok.

\section{The insertions of idioms}

This type of code mixing is refers to the insertion of idiom of one language to another language structure in one utterance or text. Idiom is an expession which has a meaning different from the individual meaning of each component or part.

Example: by the way terimakasi atas hadiahnya.

6. The insertion of one clause

This type of code mixing is refers to the insertion of part of sentence that consists of subject and predicate but do not have complete meaning into another language structure in one utterance or text.

Example: nanti saya jemput, dan kita have fun together. 


\section{The Function of Code-Mixing}

There are some functions of code mixing according to Hoffman (1991) as cited in Cakrawati (2011).

1) Talking about particular topic

People may prefer to talk about any particular topic in one language rather than in another. However, sometimes talking about any particular topic may cause a mixing in a language used by the speaker.

2) Questioning somebody else Sometimes, a speaker likes to quote a famous expression or saying of the same well-known figure or their interlocutor utterance. Those expressions or saying can be quoted intact in their original language.

3) Being emphatic about something

People who are able to speak using more than one language usually do mixing when they want to be emphatic about something.

4) Interjection (inserting sentence filler or sentence connectors)

Code mixing among bilingual can sometimes mark an interjection or sentence connector. It can be happen in unintentionally or intentionally situation.

5) Repetition used for clarification

In a condition whether a bilingual wants to clarify his/her speech, he/she will use both of the language that he masters saying the same utterance. So the interlocutor will be more understood about the meaning of his/her utterance.

6) Intention of clarifying the speech content for interlocutor
Bilingual use a lot of code mixing to make the content of his/her speech runs smoothly and can be understood by the interlocutor.

7) Expressing group identity

Code mixing can also be used to express group identity. It is because the group identity can be identified from the person way of communication.

\subsection{Code Switching \\ Definitions of Code Switching}

In multilingual societies, each language is reserved for a given situation; one is used at home, and another is used with friends and neighbors. According to Fishman (1965) as cited in Wells (2011), this situational change is referred to as code-switching, and Gumperz (1982) defines it as juxtaposition where there is exchange of passages each of which belong to different languages in its grammatical systems or subsystems. Obviously, codeswitching is the result of bilingualism. A speaker switches from one language to another according to circumstances or to given situations. In that situation, bilingual speakers will choose the language that is understandable to the interlocutor. This change is called 'situational code-switching' (Hudson, 1999 in Sinha, 2009).

But, Holmes (2001) argues that code-switching can occur within speech events or social situations. For instance, when a new person arrives, there may be change in the situation in order to greet the person by means of his language or to show speaker's 
ethnic identity, solidarity, and relationship with interlocutors. There are several attempts in defining codeswitching. Hymes (1974) in Ayemoni (2006) defines code-switching as a term which is used to indicate exchange of two or more languages, varieties of language, and can be also an exchange in style.

Crystal (2003) displays that in code-switching, people need to communicate by using two or more languages with each other, and he considers loan words as minimalist sign of code-switching. Wardhaugh (1986: 103) also gives definition of code switching occurs when the language used, changes according to the situation in which the conversant find them selves. The speakers here switch one code to another code or they speak in one language to another language.

\section{Types of Code Switching}

According to Wardhaugh

(1986) equating in this study code with language, we can describe two kinds of code switching: situational and metaphorical.

1. Situational code switching Situational code switching occurs when the languages used change according to the situations and another in a different one. No topic change is involved. When a change of topic requires a change in the language used we have

2. Metaphorical code switching

The interpreting point here is that some topics may be discussed in either code, but the choice of code adds a distinct flavor to what is said about the topic. The choice encodes certain social values. Metaphorical code switching has an affective dimension to it: you change the code as you redefine the situation formal to informal, official to personal, serious to humorous, and politeness to solidarity.

\section{The Function of Code Switching}

There are some functions of code switching in a bilingual classroom according to Olmedo-Williams(as cited in Herni 2003):

1. Regulatory (Reg) This function is to control behavior at the class and regulate turn taking.

2. Emphasis (Emp)

This function to underlie or stress a particular message. This includes switches which are produced with a louder volume of voice and a stronger tone as well as a repetition in another language.

3. Attention (Att)

This function is for gaining recognition, giving order to pupils and asserting ability.

4. Lexicalization (Lec)

This covers all switches that occur because of real lexical need which used by the speaker which does not exist in the language. The speaker realizes that particular expression in one language cannot be satisfactory translated into the second. 
5. Clarification (Cla)

Clarification is appropriate to be used when we reinsure comprehension and resolving miscommunication or ambiguity. It can be in form of repeating, paraphrasing, and elaborating ideas in another language.

6. Sociolinguistic Play (SoP)

Sometimes, there are switches done for the sake of humor to make somebody happy, testing or insulting.

7. Addressee Specification (AdP) This is used when the speaker switches the language as the speaker addressed of directed his/her speech to the different hearer.

8. Instruction (Int)

Instruction is specifically for teaching vocabulary in target language. The common form of this switch is direct translation of a word or phrase.

\section{Borrowing}

\section{The definition of Borrowing}

According to Haugen (1950) as cited in Hoffer (2005),borrowing is the process of importing linguistic items from one linguisticsystem into another, a process that occurs any time two cultures are in contactover a period of time. It is a process whereby a language incorporates a word into its vocabulary by copying it from another language. The language, whose lexical item is copied, is called donor language or source language, while the 'copying language' is called the recipient language. The term borrowing is sort of misnomer, since it entails taking something with the owner's consent and with the intention of giving it back after a period of time, but this is not the case. Even the term donor literally means one who gives/donates without expecting a return or anything in exchange but loses the item he/she/it gives. These terms are however acceptable in the field of Linguistics.

Languages are borrowed for some reasons, the most common reason is language contact. Cultures may come in contact for some reasons, and when this happens, words are transferred from one language into another especially when one language do not have a word to name a newly introduced entity or concept and the other do. As Anderson (1973:95) as cited in Premawardhena (2003) rightly puts it, "when cultures come into contact with one another, Borrowing takes place primarily in the realm of lexical item". Words that are borrowed into a language usually preserve their general sound pattern, but they also modify it according to the phonetic and phonological system of the borrowing language. (Dulay et al. 1982: 114 as cited in Adnan, 2013)

\section{Types of Borrowing a Language}

In the study language borrowing, loanwords are only one of the types of borrowings that occur across language boundaries. The speakers of a language have various options when confronted with new items and 
ideas in another language. Hockett (1958) as cited in Hoffer (2005) has organized the options as follows.

\section{(1) Loanword}

Speakers may adopt the item or idea and the source language word for each. The borrowed form is a Loanword. These forms now function in the usual grammatical processes, with nouns taking plural and/or possessive forms of the new language and with verbs and adjectives receiving native morphemes as well.

\section{(2) Loanshift}

Another process that occurs is that of adapting native words to the new meanings. A good example from the early Christian era in England is Easter, which had earlier been used for a pagan dawn goddess festival. Other Loanshiftsin English include God, heaven, and hell.

\section{(3) Loan-translation}

A Loan-translation or Calque occurs when the native language uses an item-for-item native version of the original. "Loanword" itself is a loantranslation of the German lehnwort, marriage of convenience is from the French, and long time no see is a somewhat altered version from the Chinese.

\section{(4) Loan-blend}

A Loan-blend is a form in which one element is a loanword and the other is a native element, as in the borrowed preost(priest) plus the native -had (hood) in Old English to produce preosthad(priesthood).
Each of these four categories is relevant to the overall study of the scale of receptivity, but for the purposes below only the loanword category is relevant.

\section{Borrowing in English}

1. Latin Influence: With the introduction of Christianity by the Romans in 597, many Latin words were introduced to English. Latin was the language of the services. Schools were established in the monasteries and the large schools. Many Latin words related to the church and its services were borrowed: nun, priest, pope, angel, temple. Other words related to education were: school, master, grammatical, verse.

2. French Influence on

English: Because of the Norman invasion of England in the 11th Century, the French nobility held all the important positions in the country. Thus, many French words were borrowed, for instance: baron, baroness, count, countess, duke, duchess, prince, princess, noble, royal.

3. Spanish and Italian words: Spanish: armada, alligator, canyon, guitar, mosquito, ranch, taco, tornado, tortilla.

Italian :casino, macaroni, piano, opera, prima donna, soprano, studio, violin

Italian American immigrants: cappuccino, espresso, pasta, pizza, ravioli, spaghetti 


\section{Arabic Influence on English:}

By 11th and 12th centuries, Arabic civilization had fully spread through Spain. This Muslim conquest of the mainland influenced medieval European scholars who began to take an interest in Arabic learning, most notably in mathematics chemistry and astronomy, e.g., algebra, amalgam, zenith, algorithm, and the stars of the stars Algol and Alnath.

\section{English Influence on Indonesian}

Indonesian borrow many English words to be as an Indonesian language which uses daily, for example:

\begin{tabular}{|l|l|l|}
\hline $\begin{array}{l}\text { BORROWING } \\
\text { WORDS }\end{array}$ & STATE & MEANING \\
\hline $\begin{array}{l}\text { Television, } \\
\text { hammer, } \\
\text { bussiness }\end{array}$ & English & $\begin{array}{l}\text { Televisi, } \\
\text { pemukul, } \\
\text { bisnis }\end{array}$ \\
\hline $\begin{array}{l}\text { Benzine , boss, } \\
\text { lottery }\end{array}$ & Dutch & $\begin{array}{l}\text { Bensin, bos, } \\
\text { lotere }\end{array}$ \\
\hline $\begin{array}{l}\text { Opera, studio, } \\
\text { verse, datum, } \\
\text { alumnus }\end{array}$ & Latin & $\begin{array}{l}\text { Opera, } \\
\text { studio, versi, } \\
\text { data, alumni }\end{array}$ \\
\hline Armada, guitar & Spanish & $\begin{array}{l}\text { Armada, } \\
\text { gitar }\end{array}$ \\
\hline Noble, gown & Italian & $\begin{array}{l}\text { Bangsawan, } \\
\text { gaun }\end{array}$ \\
\hline Dacing & China & Timbangan \\
\hline Shampoo & Hindi & Sampo \\
\hline
\end{tabular}

\section{Pidginization}

\section{Definition of Pidginization}

Pidgin is a language which has no native speaker (Sawant, 2011). It develop as a means of communication between people who do not have a common language. Pidginization is a process of language simplification. This simplification process usually includes the removal of inflection, reduction of preposition used, overgeneralization of rules, and making tense distinctions by markers such as "now" and "after" rather than the modification of the verb itself (Todd, 1984) as cited in Schuit (2008). Pidgins are considered as 'broken languages'. If they are compared with otherlanguages or with their lexifiers, i.e. the source language of words pidgin, it is found that thereare many reducing in their structure (C. Llamas C, Mullany L., \&Stockwell P. (2006:177).

As Yole (2006)illustrates, if English, for instance, is the source language of words in pidgin, this does notnecessitate that they must pronounce them as the same as in the source language. There arenumerous examples of English pidgins where there is a noticeable absence of complex grammatical morphology and a presence of a limited number of vocabularies. For instance, the suffixes of ' $s$ ' which points to the plural in English are absent in pidgin. Besides, the phrase 'two books' is diminished to 'tubuk'.

UNESCO (1963:46) as cited in Jacob (2014) defines pidgin as follows: A language which has arisen as the result of contact between people of different languages usually formed a mixing of the languages. Pidgin vocabulary is taken from the dominant group. For example, some migrants of traders who come from Turkey, but live in Germany, will not create a pidgin whose vocabulary is emerged or derived from Turkish because it is difficult for German people to learn it. So, they will use 
the vocabulary of German (Holmes, 2001).

Example of English language pidgin, English pronunciation essentially adapted to the Indonesian (Sumarsono, 2002: 147).

$\begin{array}{ll}\text { Peri cip } & =\text { very cheap } \\ \text { Paip } & =\text { five } \\ \text { Masas } & =\text { massage } \\ \text { Ting } & =\text { thing } \\ \text { Tosen } & =\text { thousand } \\ \text { Sik } & =\text { sick }\end{array}$

The following sentences were also found :

You want run? Anda ingin lari? (there is no "do" and "to")

Oh, you alone. Oh, anda sendiri, (there is no "are")

\section{Creolization \\ Definition of Creolization}

Lyon (1984) stated that once pidgin becomes the first language of children, it is called: creole. According to Holmes (2001), a creole is a pidgin which has acquired native speaker. As Aitchison (1994, p. 3177) in Priyanto (2009) says, 'creoles arise when pidgins become mother tongues.' A creole, therefore, is a 'normal' language in almost every sense. The famous examples of creoles are the English-based creole of Jamaica and the French-based creole of Haiti. Moreover, Hawaii creole English is spoken by a great numbers of native speakers (Yole, 2006). When pidgin develops to creole, it is described as creolization. Creole is a pidgin which is modified and appropriated in its structure and vocabulary (Holmes, 2001).
So, the grammatical features of creole will be changed and modified in order to be standard variety (Holmes, 2001). But, a creole may stay stable as low variety. For instance, the case of Haiti in which creole is L variety and French is $\mathrm{H}$ variety (Holmes, 2001). When creole has developed, it can be used in different domains as in politics, education, and administration and so on.

TokPisin is used in the Papua New Guinea Parliament. The name TokPisin, Tokwas been derived from 'talk' in English andPisin from 'Pidgin'. However TokPisin has now achieved independent language status as a creole, which is a language with its origins usually in a Pidgin but which has a substantial number of speakers who use it as their primary language (Dasgupta, nd). Along with English and Hiri Motu, TokPisin is now one of the three official languages of Papua New Guinea.

\section{Conclusion}

In conclusion, there are some different patterns of language use, including code-mixing, codeswitching, borrowing, pidginization and creolization. The code can be a variety related to the element of language like sentence, clause, phrase and word which have the limitation because the code which is chosen by the speaker based on his/her necessity in communicating. CodeMixing is the mix of code from two languages or more in some content of conversation in form of a sentence, 
while Code-Switching defined as a term which is used to indicate exchange of two or more languages, varieties of language, and can be also an exchange in style. Moreover, Borrowing is the process of importing linguistic items from one linguistic system into another, a process that occurs any time two cultures are in contact over a period of time. Furthermore, Pidginization is a simplification of code of language which has arisen as the result of contact between people of different languages usually formed a mixing of the languages. When pidgin develops to creole, it is described as creolization. Creole is a pidgin which is modified and appropriated in its structure and vocabulary.

\section{References:}

Adnan, K. (2013). Contrastive Linguistics and Contrastive Analysis Hypothesis. Retrieved January Ayeomoni, M.O. 2006. Code-Switching and Code-Mixing: Style of Language Use in Childhood in Yoruba Speech Community. Nordic Journal of African Studies. Obafemi Awolowo University, Ile-Ife, Nigeria. Pdf

Cakrawati, D. A. (2011). Analysis of Code Switching and Code Mixing in the Teenlit Canting Cantiq by Dian Nuranindya.

Crystal, David (2003) English as a Global Language. 2nd edition. Cambridge: Cambridge University Press.
Dasgupta. (nd). TokPisin: Papua New Guinean Creole.

Gumperz, Jhon J. (1982). Discourse Strategies (Studies in International

Sociolinguistics). Hoffer, B. L (2005). Language Borrowing and Language Diffusion:*an Overview.

Sawant, N. R. (2011). Pidgin: An Admixture of Different Elements. Retrieved January $29^{\text {th }}, \quad 2015$ from r.search.yahoo.com/_ylt=A86. JyFHw9dU2HwAYHwnnIlQ; _ylu=X3oDMTEzajI4YnBhBH NlYwNzcgRwb3MDNQRjb2 xvA2dxMQR2dGlkA1lIUzA wM18x/RV=2/RE=1423455175 $/ \mathrm{RO}=10 / \mathrm{RU}=\mathrm{http} \% 3 \mathrm{a} \% 2 \mathrm{f} \% 2 \mathrm{f}$ www.thecriterion.com $\% 2 \mathrm{fV} 2 \% 2 \mathrm{fn} 4 \% 2 \mathrm{f}$ NRSawant.pdf/RK=0/RS=12Sa jeUqzZfBrM7NrJ5eOym94II-

Schuit, J. C. (2008). Pidginization Exemplified in Haitian-Creole and Tok-Pisin.

Sinha, Smita. (2009). Code Switching and Code Mixing Among Oriya Trilingual Children - A Study.

Sumarsono., 2002. Sosiolinguistik. Lembaga Studi Agama , Budaya dan Perdamaian. Yogyakarta

Suryani, Heni. (2013). Analisis Code Mixing Dalam Novel Fat Bulous.

Wardaugh, Roland. (1998). An Introduction to Sociolinguistic (3rd Edition) Massachusetts: Blackwell Publisher Inc. 
Wells, Megan. (2011). Codeswitching in the comedy of George Lopez.

Wisesa, S. I. (2012). Penggunaan Campur Kode.

Wolfram, Walt. (1991). Dialects and American English. Englewood Cliffs, NJ:
Prentice Hall (to be reissued by Basil Blackwell in 1998 as American English: Dialects and variation).

Yole, G. (2006). The Study of Language. 3rd (ed.). Cambridge: Cambridge University Press. 